Wiktor Werner

(Uniwersytet im. Adama Mickiewicza w Poznaniu)

dr hab., werner@amu.edu.pl

ORCID iD: 0000-0002-3004-6021

Dawid Gralik

(Uniwersytet im. Adama Mickiewicza w Poznaniu)

mgr,dgralik@o2.pl

ORCID iD: 0000-0003-2093-4938

Adrian Trzoss

(Uniwersytet im. Adama Mickiewicza w Poznaniu)

mgr, adrian.trzoss@amu.edu.pl

ORCID iD: 0000-0002-6287-418X

\title{
Media społecznościowe a funkcjonowanie wiedzy historycznej w Polsce. Raport z badań
}

W 1998 r. Jan Pomorski pisał: „Zakłada się tu, iż historiografia wpływa, mniej lub bardziej bezpośrednio, na stan wiedzy i sposób myślenia historycznego społeczeństwa, a jednocześnie ona sama jest emanacją społecznych wyobrażeń o przeszłości, swoistym zapisem samoświadomości historycznej pokolenia"1.

Mając na uwadze słowa Pomorskiego, chcielibyśmy odnieść powyższą kwestię do aktualnych problemów badawczych. Zatem pierwszą przesłanką dla przeprowadzenia badań będących podstawą tego tekstu był obserwowalny na przestrzeni ostatnich kilku lat gwałtowny wzrost znaczenia mediów społecznościowych dla całokształtu życia społecznego, politycznego oraz ekonomicznego. Wzrost tego znaczenia wiązał się z tak dramatycznymi, jak i niespodziewanymi wydarzeniami, wśród których wynik brytyjskiego refe-

${ }^{1}$ J. Pomorski, Przyszli historycy o historii. Z badań nad świadomością historyczna Polaków w latach 1987-1988, [w:] tegoż, Spoglądając w przeszłość. Studia i szkice metahistoryczne, J. Pomorski, Lublin 2017, s. 53. 
rendum (za pozostaniem bądź wyjściem z Unii Europejskiej) można postawić niewątpliwie na pierwszym miejscu². Tematem bulwersującym jest nie tylko to, że podejmujący decyzje wyborcy korzystają z mediów społecznościowych i głosują, kierując się wiedzą dostarczaną przez te media, lecz także fakt, że docierające do danych grup społecznych informacje mogą być precyzyjnie kształtowane, w taki sposób, aby wspierać określone obawy, fobie czy nadzieje. Media społecznościowe stały się (niekoniecznie pozytywnym) bohaterem wielu książek, programów publicystycznych oraz produkcji filmowych, a zagadnienie edukowania społeczeństwa w zakresie mechanizmów ich działania, uznano za priorytetowe ${ }^{3}$. Kwestia świadomości użytkowników mediów społecznościowych jest sprawą nadzwyczajnej wagi, gdyż jak zostało to podkreślone w przypadku afery Cambridge Analytica, użytkownicy Facebooka dobrowolnie, lecz prawdopodobnie bezwiednie przekazywali swoje dane aplikacji, a te później (na co wskazuje dotychczasowe śledztwo ${ }^{4}$ ) zostały wykorzystane $\mathrm{w}$ celach marketingu politycznego $\mathrm{z}$ użyciem algorytmów profilujących 5 .

Przesłanką drugą jest wzrastające znaczenie tzw. public history (twórczości historycznej tworzonej $\mathrm{w}$ wyniku żywego zapotrzebowania społecznego, niekoniecznie przez profesjonalnych historyków), zjawiska przyciągającego uwagę badaczy historiografii i myślenia historycznego od końca lat 70. $\mathrm{XX}$ w. ${ }^{6}$

Kolejną inspiracją dla naszych badań były prace Jana Pomorskiego, analizujące społeczne zapotrzebowanie na historiografię oraz świadomość historyczną Polaków w późnych latach 80 . oraz $90 .{ }^{7}$ Pomorski poruszał w nich temat sprzężenia między przyspieszającymi zmianami społecznymi, politycznymi a tymi w świadomości historycznej i przekładania się jej na aktywizm historyczny rozumiany jako konkretne postawy i działania. Naszym proble-

2 C. Cadwalladr, The Great British Brexit Robbery: How Our Democracy Was Hijacked, "Guardian" z 7 maja 2017, https:/ / www.theguardian.com/technology/2017/may/07/the-great-british-brexit-robbery-hijacked-democracy (dostęp: 21.092019).

${ }^{3}$ The Great Hack, reż. K. Amer, J.Noujaim, 26 stycznia 2019; Brexit: The Uncivil War, reż. T. Haynes, 7 stycznia 2019.

${ }^{4}$ Z. Tufekci, Facebook's Surveillance Machine, "The New York Times" z 19 marca 2018, https://www.nytimes.com/2018/03/19/opinion/facebook-cambridge-analytica.html (dostęp: 21.09.2019).

${ }^{5}$ S.C. Matz, M. Kosinski, G. Nave, D.J. Stillwell, Psychological Targeting as an Effective Approach to Digial Mass Persuasion, "Proceedings of the National Academy of Sciences of the United States of America" 2017, vol. 114, Issue 48, s. 12714-12719; M. Kosinski, S.C. Matz, S.D. Gosling, V. Popov, D. Stillwell, Facebook as a research tool for the social sciences: Opportunities, challenges, ethical considerations and practical guidelines, "American Psychologist” 2015, vol. 70, Issue 6, s. 543-556.

${ }^{6}$ F. Sayer, Public History. A Practical Guide, Bloomsbury 2019, s. 28-36.

${ }^{7}$ J. Pomorski, dz. cyt., s. 29-51; tegoż, Przyszli historycy o historii. Z badań nad świadomościa historyczną Polaków w latach 1987-1988, [w:] tegoż, Spogladając w przeszłość..., s. 53-87. 
mem badawczym są z kolei następujące zagadnienia: jak wygląda relacja między użytkowaniem mediów społecznościowych a świadomością historyczną ich użytkowników; jakiego rodzaju piśmiennictwo historyczne powstające w sieci Polacy dziś „konsumują" i „prosumują” (również w ujęciu popularnonaukowym $)^{8}$; wreszcie jak rysują się proporcje podstawowych wypadkowych społecznej świadomości historycznej, czyli wiedzy naukowej, wiedzy potocznej oraz polityki historycznej, a także jej kolejnego znaczącego elementu - funkcji rozrywkowej.

Wybrany obszar badawczy jest zasadniczo sprawą szeroką, wymagającą znacznego zawężenia materiału poddanego analizie, przy jednoczesnym staraniu o jak najbardziej reprezentatywne wnioski. W czasach powszechnego dostępu do Internetu ograniczenie pojęciowe „internauci” do jakiejś odizolowanej od ogółu społeczeństwa grupy wydaje się tracić na znaczeniu. W przypadku, w którym praktycznie każdy Polak w dowolnym momencie może zalogować się do Facebooka, nie należy rozdzielać tych dwóch przestrzeni życiowych. Stąd naturalną konsekwencją jest podjęcie badania pewnego wycinka całokształtu ludzkiej aktywności. Na wstępie zatem chcielibyśmy przedstawić kilka zastrzeżeń, poczynionych przed przeprowadzeniem właściwego badania, które przyjęło formę ankiety.

Po pierwsze - z całej gamy mediów społecznościowych postanowiliśmy wybrać dwa najbardziej popularne portale, tj. Facebook oraz Youtube ${ }^{9}$ Na rzecz takiego doboru próby przeważa nie tylko fakt ich wzajemnej komplementarności (tekstualność oraz wizualność); wiele z badanych przez nas środków przekazu (fanpage'ów oraz kanałów) korzysta z obu platform, przez co możliwe było przebadanie większej grupy odbiorców oraz pełniejsze prześledzenie treści historycznych używanych w ich działalności. Ponadto Facebook ze swoją mechaniką angażowania odbiorców zdaje się obecnie wywierać największy ze wszystkich mediów społecznościowych wpływ na realność pozacyfrową ${ }^{10}$.

Po wtóre, odwołując się do badań medioznawczych, chcielibyśmy zwrócić uwagę na fakt coraz większego znaczenia „wizualności” wśród młodych ludzi, którzy zdają się najlepiej zaznajomieni są ze światem cyfrowym, stanowiąc przy tym ciekawą podgrupę badanych, szczególnie wobec ekspansji tzw. kultury obrazkowej ${ }^{11}$. W poniższym przypadku Facebook reprezentuje

${ }^{8}$ Prosumpcja: pomiędzy podejściem apokaliptycznych a emancypujacym, red. P. Siuda, T. Żaglewski, Gdańsk 2014.

${ }^{9}$ J. Clement, Most Popular Social Networks Worldwide as of July 2019, https:/ /www.statista. com/statistics/272014/global-social-networks-ranked-by-number-of-users/ (dostęp: 21.09.2019).

${ }^{10}$ C. Sunstein, \#Republic: Divided democracy in the age of social media, Princeton University Press 2017.

${ }^{11} \mathrm{Na}$ temat kultury obrazkowej zob.: K. Litwic-Kamińska, Kultura obrazkowa w dydaktyce szanse i zagrożenia, „Forum Dydaktyczne” 2011, nr 7-8, s. 177-188; G. Sartori, Homo videns: te- 
warstwę nie tylko tekstualną, ale i wizualną, w postaci obrazów, memów oraz gifów, Youtube zaś - filmu. Proces przekształcania się społeczeństwa w stronę określoną przez Giovanniego Sartoriego ${ }^{12}$ jako homo videns, zmienia rozłożenie akcentów $\mathrm{w}$ partycypacji $\mathrm{w}$ danym medium ${ }^{13}$. W przypadku Web 2.0 mamy do czynienia $\mathrm{z}$ daleko idącymi zmianami pod znakiem medium is the message Marshalla MacLuhana ${ }^{14}$, a także kultury uczestnictwa, jak w przypadku Youtube'a, o czym pisali m.in. Jean Burgess oraz Joshua Green ${ }^{15}$. Medium, a w przypadku mediów społecznościowych coraz częściej mówi się o metamedium $^{16}$, nie jest jedynie neutralnym przekaźnikiem, ale znacząco wpływa na odbiór i partycypację w obiegu informacji ${ }^{17}$. Stąd warto zastanowić się, jakie ma to znaczenie dla odbioru treści historycznych, tworzenia się wszelkich wyobrażeń na temat przeszłości - utwierdzania się stereotypów związanych $\mathrm{z}$ wiedzą potoczną oraz powstawaniem teorii pseudonaukowych o charakterze spiskowym ${ }^{18}$.

Po trzecie - odwołując się do krajowego dyskursu badawczego, wzięto pod uwagę polskojęzyczne środki przekazu, poświęcone stricte tematyce historycznej (amatorskie i popularnonaukowe). Pośród nich dokonana została dywersyfikacja - jako próba wybrane zostały zarówno te największe, jak $\mathrm{i}$ te dopiero rozwijające się; hobbystyczne, specjalistyczne i te o tematyce szerokiej, autorskie i stanowiące przedłużenie działalności portali popularnonaukowych. Podobnie kwestia dotyczyła grup docelowych - uczniów, studentów, pracowników naukowych i wreszcie przeciętnych użytkowników w pełnym przedziale grup wiekowych.

Biorąc pod uwagę powyższe zastrzeżenia, w badaniu pojawiło się piętnaście fanpage'ów/kanałów funkcjonujących w ramach Facebooka i YouTube:

lewizja i post-myślenie, przekł. J. Uszyński, Warszawa 2005; J.D. Bolter, R. Grusin, Remediation. Understanding New Media, MIT Press 1999.

12 G. Sartori, dz. cyt.

${ }^{13}$ J.D. Bolter, R. Grusin, dz. cyt.

${ }^{14} \mathrm{~W}$ opinii badacza, samo medium również stanowi element przekazu, stając się jego integralną częścią. M. MacLuhan, Understanding Media. The extensions of man, London-New York 1964, s. 7-24.

${ }^{15} \mathrm{~J}$. Burgess, J. Green, Youtube: wideo online a kultura uczestnictwa, tłum. T. Płudowski, Warszawa 2011.

${ }^{16}$ M. Filiciak, Internet - społeczne metamedium, [w:] Media audiowizualne, red. W. Godzic, Warszawa 2010, s. 104-124.

${ }^{17}$ L. Manovich, Software Takes Command: Extending the Language of New Media, New York 2013.

${ }^{18}$ R. Żuchowicz, Wielka Lechia. Źródła i przyczyny popularności teorii pseudonaukowej okiem historyka, Warszawa 2018; W. Werner, A. Trzoss, Czy cyfrowe media wywotuja społeczna paranoję? Dwugłos w sprawie obecności teorii spiskowych w mediach społecznościowych i kulturze masowej, „Nauka” 2019, nr 3, s. 147-169. 
Ciekawostki historyczne ${ }^{19}$ (ok. 222 tys. polubień ${ }^{20)}$, Histmag.org ${ }^{21}$ (ok. 78 tys.), Historia.org.pl - Polski portal historyczny ${ }^{22}$ (ok. 40 tys.), Historia bez cenzu$r y^{23}$ (ok. 191 tys.), Historia $i$ wojskowość - wszystko, czego mógłbyś nie wiedziećc (ok. 2,8 tys.), Historia w 5 minut ${ }^{25}$ (ok. 8,4 tys.), Historycy.org ${ }^{26}$ (ok. 18 tys.), Historyczne bzdury ${ }^{27}$ (ok. 18 tys.), Historykon.pl $l^{28}$ (ok. 74 tys.), Hrabia Tytus ${ }^{29}$ (ok. 14 tys.), II wojna światowa w kolorze ${ }^{30}$ (ok. 35 tys.), Napoleon. org.pl $l^{31}$ (ok. 4,1 tys.), Ohistorie ${ }^{32}$ (891), Sigillum Authenticum ${ }^{33}$ (ok. 4,6 tys.), ThrashingMadPL ${ }^{34}$ (ok. 4,5 tys.).

Po dokonaniu powyższego wyboru przygotowane zostało badanie z użyciem metody sondażowej na grupie 2233 respondentów. Jego celem było, jak zaznaczyliśmy wcześniej, zbadanie świadomości historycznej użytkowników social mediów, a w dokładniejszym zakresie subskrybentów powyższych portali. Dzięki zamieszczeniu w ankiecie pytań dotyczących innych środków przekazu (filmów, seriali, gier wideo, portali internetowych o tematyce historycznej) możliwe było dokonanie porównania aspektów współkształtowania świadomości historycznej Polaków poprzez te media, które powstały przed erą Web 2.0, w porównaniu z mediami społecznościowymi.

\footnotetext{
${ }^{19}$ Strona Ciekawostki historyczne, https://www.facebook.com/ciekawostkihistoryczne/ (dostęp: 15.05.2019).

${ }^{20}$ Stan liczby polubień na 11.04.2019 r.

${ }^{21}$ Strona Histmag.org, https://www.facebook.com/histmag.org/?ref=br_rs (dostęp: 15.05.2019).

${ }^{22}$ Strona Historia.org.pl, https://www.facebook.com/historiaorgpl/?ref=br_rs (dostęp: 15.05.2019).

${ }^{23}$ Strona Historia bez cenzury, https://www.facebook.com/historiabezcenzury/ (dostęp: 15.05.2019).

${ }^{24}$ Strona Historia i wojskowość - wszystko czego mógłbyś nie wiedzieć, https:/ / www.facebook. com/Historia-i-wojskowo \% C5\%9B\%C4\%87-wszystko-czego-m \%C3\%B3g\%C5\%82by \% C5\%9Bnie-wiedzie\%C4\%87-1710778358946910/ (dostęp: 15.05.2019).

${ }^{25}$ Strona Historia w 5 minut, https://www.facebook.com/historiaw5minut/ (dostęp: 15.05.2019).

${ }^{26}$ Strona Historycy.org, https:/ / www.facebook.com/historycy/ (dostęp: 15.05.2019).

${ }^{27}$ Strona Historyczne bzdury, https://www.facebook.com/historycznebzdury/ (dostęp: 15.05.2019).

${ }^{28}$ Strona Historykon, https://www.facebook.com/historykon/?ref=br_rs (dostęp: 15.05.2019).

${ }^{29}$ Strona Hrabia Tytus, https:/ / www.facebook.com/Hr.Tytus/ (dostęp: 15.05.2019).

${ }^{30}$ Strona II wojna światowa w kolorze, https:/ / www.facebook.com/WojnawKolorze/ ?ref=br_ rs (dostęp: 15.05.2019).

${ }^{31}$ Strona Napoleon.org, https://www.facebook.com/napoleonorgpl/?ref=br_rs (dostęp: 15.05.2019).

32 Strona Ohistorie, https://www.facebook.com/ohistorie/ (dostęp: 15.05.2019).

${ }^{33}$ Strona Sigillum authenticum, https://www.facebook.com/sigillum.authenticum/?ref =br_rs (dostęp: 15.05.2019).

${ }^{34}$ Strona Thrashingmadpl,https:/ / www.facebook.com/Thrashingmadpl-248440875304443/ (dostęp: 15.05.2019).
} 
Podczas konstruowania formularza ankiety oraz projektowania spodziewanych wyników funkcję pomocniczą pełniły efekty pracy agencji sondażowych CBOS oraz OBOP, które prowadziły liczne badania szczegółowe oraz o charakterze bardziej ogólnym dotyczące stosunku Polaków do różnych aspektów świadomości historycznej i społecznej funkcji historii ${ }^{35}$. Ponadto odwoływaliśmy się do prac naukowych z dyskursu badań nad świadomością historyczną w Polsce. Należy tutaj wymienić badania przeprowadzone przez socjologów Ninę Assorodobraj-Kulę oraz Barbarę Szacką w latach 60. oraz Jana Pomorskiego w latach 1987-1988 ${ }^{36}$, badania Janusza Rulki ${ }^{37}$, a także nowsze, jak np. Łukasza Michalskiego ${ }^{38}$. Poza środowiskiem akademickim kwestia ta jest często diagnozowana przez agencje sondażowe, chocby CBOS czy OBOP, od tych najbardziej szczegółowych (np. Wotyń 1943 - pamięć przywracana oraz Czy w Warszawie potrzebne sa nowe pomniki?) po refleksje natury bardziej ogólnej, a przez to zdaje się ciekawszej, jeśli chodzi o stosunek Polaków do własnej przeszłości (przeprowadzone w 2016 r. badania dotyczące świadomości historycznej Polaków w 1050. rocznicę chrztu Polski oraz analogiczne wcześniejsze z 1988 r. pt. Przeszłość jako przedmiot zainteresowań $i$ dyskusji we wspótczesnym społeczeństwie polskim ${ }^{39}$ ). Nasze badanie wpisuje się zatem w rozbudowany dyskurs nie tylko akademicki, lecz będący również przedmiotem zainteresowania polityków i ogółu społeczeństwa. Biorąc pod uwagę dorobek związany $\mathrm{z}$ omawianym przez nas problemem, postanowiliśmy przyjrzeć się efektom, a dokładniej postawom wobec treści historycznych, traktując jako punkt wyjścia do interpretacji przyczyn takiego stanu rzeczy całość dotychczasowego dyskursu.

Badanie sondażowe zostało przeprowadzone na próbie subskrybentów mediów społecznościowych Facebooka oraz Youtube'a. Praktycznie niemożliwym jest oszacowanie całkowitej populacji ze względu na płynność w liczbie aktualnych subskrybentów badanych mediów. Niemniej jednak, jak okazuje się w dalszej części badania, odpowiedzi zostały udzielane głównie przez zaangażowanych "fanów” - mamy zatem do czynienia z grupą reflektującą

${ }^{35}$ A. Wysocki, Stosunek społeczeństwa polskiego do przeszłości a tożsamość narodowa. Analiza badań sondażowych, "Annales Sectio I Philosophy and Sociology" 2018, vol. 43, 1, s. 111-124; M. Bożewicz, Świadomość historyczna Polaków, „Komunikat z badań” 2016, nr 68 CBOS.

${ }^{36}$ B. Szacka, Świadomość historyczna (Wnioski z badań empirycznych), "Studia Socjologiczne” 2011, 1(200), s. 233-260; oryginał: "Studia Socjologiczne” 1977, 3(66) s. 66-103.; J. Pomorski, dz. cyt.; Ł. Michalski, Kilka uwag o mitach na temat świadomości historycznej Polaków, [w:] Historycy i politycy: polityka pamięci w III RP, red. P. Skibiński, T. Wiścicki, M. Wysocki, Warszawa 2011, s. 193-209; N. Assorodobraj, „Żywa historia”. Świadomość historyczna: symptomy i propozycje badawcze, „Studia Socjologiczne” 1963, nr 2, s. 5-45.

37 J. Rulka, Przemiany świadomości historycznej młodzieży, Bydgoszcz 1991.

${ }^{38}$ Ł. Michalski, dz. cyt., s. 193-209.

${ }^{39}$ Przeszłość jako przedmiot zainteresowań i dyskusji we wspótczesnym społeczeństwie polskim, CBOS 1988. 
w stopniu przynajmniej minimalnym nad ich partycypacją w odbiorze treści historycznych. Liczne badania natury jakościowej zwykły się skupiać na kwestiach przyczyn oraz skutków procesów historycznych powiązanych z polityką historyczną czy po prostu wydarzeniami natury społeczno-politycznej. Na rzecz przyjętego przez nas modelu badania sondażowego przesądza kwestia podejścia ilościowego, wychodzącego poza ramy teoretycznych rozważań, a skupiająca się na kwestii codziennych praktyk respondentów. Obrane przez nas podejście miałoby zatem odgrywać rolę uzupełnienia dotychczasowego stanu literatury, a nie przesądzenia o absolutnym charakterze wniosków sformułowanych na podstawie przeprowadzonego sondażu.

Formularz ankiety przygotowanej dzięki narzędziu Google ${ }^{40}$ składał się z 28 pytań podzielonych na następujące kategorie: dane dotyczące respondenta, źródła wiedzy historycznej respondenta, preferencje i zainteresowania historyczne respondenta, ocena wartości merytorycznej wybranych zagadnień, a także zagadnienie edukacji historycznej i polityki historycznej. Badanie zostało przeprowadzone 13-25 marca 2019 r. za pośrednictwem Internetu. Celem uzyskania satysfakcjonującego poziomu zwrotów formularz był rozpowszechniany na następujących fanpage'ach oraz kanałach: Historia w $5 \mathrm{mi-}$ nut, Hrabia Tytus, Sigillum Authenticum, ThrashingMadPL, Ohistorie, Sekcja Archeologii Biblioteki Wydziału Historycznego UAM, Polska antropologia fizyczna, Studenckie Koło Naukowe Historyków Starożytności i Średniowiecza UWr, Koło Metodologiczne Historyków UMCS, Historyczne bzdury, II wojna światowa w kolorze, a także pośród uczniów szkół ze Szczecina, Poznania oraz Trójmiasta, a także studentów Wydziału Historycznego UAM.

Wyniki przeprowadzonej ankiety w poszczególnych częściach prezentują się następująco ${ }^{41}$.

Na kategorię „dane ogólne” składały się pytania dotyczące podstawowych elementów charakteryzujących ankietowanych za pomocą następujących zmiennych: płeć, wiek, miejsce zamieszkania, wykształcenie, związek wykształcenia $\mathrm{z}$ historią lub naukami pokrewnymi. $\mathrm{W}$ badaniu wzięło udział 1772 mężczyzn (79,4 proc.) oraz 461 kobiet (20,6 proc.), co zdaje się potwierdzać dotychczasowe badania ${ }^{42}$, wskazujące na podobny rozkład zainteresowania wśród płci. Jest to o tyle interesujące, iż zauważalny jest związek między

${ }^{40}$ Formularze Google: https://docs.google.com/forms/u/0/ (dostęp: 21.09.2019).

${ }^{41}$ Pytania posiadały dwa stopnie obligatoryjności: opcjonalne oraz obowiązkowe, bez wypełnienia których nie było możliwe ukończenie całego formularza. Tam, gdzie nie zaznaczono inaczej, omawiane odpowiedzi były wymogiem obowiązkowym.

${ }^{42}$ Raport Polacywobechistorii-zainteresowanieawiedza, http://www.tnsglobal.pl/archiwumraportow/2014/04/04/polacy-wobec-historii-zainteresowanie-a-wiedza/ (dostęp: 21.09.2019); D. Gralik, Wptyw gier wideo na wiedze historyczna i popularyzacje historii, [w:] Popularyzacja nauk historycznych - teoria i praktyka. Zbiór studiów, red. D. Gołaszewska-Rusinowska, M. Mielewska, T. Sińczak, Torun 2018, s. 181-192. 
zainteresowaniem polityką oraz historią, co może stanowić efekt rozumienia historii politycznie zorientowanej historiografii opartej na faktografii „zdarzeniowej". Największą reprezentacją badanych były osoby poniżej dziewiętnastego roku życia, a zatem uczniowie szkół podstawowych oraz średnich (924 osoby - 41,4 proc.). Kolejne grupy wiekowe: 19-25 lat (z przeprowadzonych analiz korelacji wynika, iż w grupie tej dominowali studenci) oraz 26-40, stanowią odpowiednio 33,9 proc. (757 respondentów) oraz 19,5 proc. (436 respondentów). Do najmniej licznych grup zaliczają się osoby w wieku 41-65 oraz powyżej 65. roku życia (odpowiednio 110 osób, co stanowi 4,5 proc., oraz 6 osób, mniej niż 1 proc. ${ }^{43}$ ). Powyższe dane wskazują, iż głównie osoby młode realizują swoje zainteresowania historyczne w mediach społecznościowych, podczas gdy osoby starsze sięgają do mediów bardziej tradycyjnych: telewizji, radia, prasy specjalistycznej czy, w wymiarze Internetu, stron o tematyce historycznej niezwiązanych z mediami społecznościowymi (tradycyjnych stron WWW). Warto zwrócić także uwagę na fakt, iż ponad dziewięćdziesiąt proc. respondentów przynależy wiekowo do pokolenia „dojrzewającego" wraz z rozwojem technologii cyfrowych oraz Internetu, co może potencjalnie wpływać na ich perspektywę poprzez swoistą oczywistość istnienia nowych mediów $w$ ich codziennym życiu ${ }^{44}$. Najliczniejszą grupą badanych były osoby pochodzące $z$ największych miast $w$ Polsce, tj. powyżej dwustu tys. mieszkańców ( 881 odpowiedzi - 39,5 proc.). Pozostałe trzy grupy rozkładają się następująco: osoby z miast w przedziale 50-200 tys. stanowiły 16 proc. badanych (358 respondentów), z miejscowości od 10 do 50 tys. również 16 proc. (359 odpowiedzi), natomiast przedstawiciele małych miast i wsi stanowią drugą co do wielkości grupę 28,4 proc. ankietowanych (635 odpowiedzi). Obserwujemy zatem znaczną dominację osób pochodzących z wielkich miast, przy równomiernej reprezentacji osób z pozostałych części Polski. Sytuacja ta może mieć związek z następującym parametrem, jakim jest kwestia wykształcenia, a także z poprzednim, czyli wiekiem. Duże miasta przyciągają studentów oraz młodsze osoby szukające pracy. W kwestii wykształcenia wyniki prezentują się następująco: podstawowe - 29,5 proc. (659 odpowiedzi), średnie - 40,7 proc. (909 odpowiedzi), wyższe - 27,8 proc. (620 odpowiedzi), oraz zawodowe -2 proc. (45 odpowiedzi). Przeprowadzone analizy potwierdzają związek wieku z wykształceniem, co będzie pomocne w przygotowaniu charakterystyki statystycznego ankietowanego. Ostatnią zmienną w tej części ankiety jest odpowiedź na następujące pytanie: „Czy wykształ-

${ }^{43}$ Ze względu na niewielki, a zatem nieznaczący statystycznie odsetek osób powyżej 65. roku życia odpowiedzi te zostały pominięte w dalszej części tekstu.

${ }^{44}$ WWW istnieje już prawie trzydzieści lat. Social media z kolei pojawiły się na fali Web 2.0 od początku 2004 r., zatem większy wpływ mają w grupie osób poniżej dziewiętnastego roku życia. 
cenie Pani/a ma związek z historią lub naukami pokrewnymi (archeologia, historia sztuki itp.)?" Większość ankietowanych (71,9 proc. - 1605 osób) zadeklarowała brak takiego związku (wobec 28,1 proc. - 628 osób). Mamy zatem do czynienia z przewagą hobbystów oraz amatorów historii nad grupą profesjonalistów, co daje możliwość zestawienia postaw i preferencji zarówno u osób mających formalne wykształcenie historyczne, jak i pozostałych. Mając na uwadze powyższe dane, otrzymujemy następujący obraz statystycznego ankietowanego: jest to młody mężczyzna, uczący się lub studiujący w dużym ośrodku miejskim, bez wykształcenia w ramach nauk historycznych. Porównując otrzymane rezultaty z dotychczasowymi badaniami opinii publicznej prywatnych agencji sondażowych, otrzymujemy zbliżoną charakterystykę, czyli pasjonata-hobbysty, którego zainteresowania historyczne nie wynikają bezpośrednio z jego wykształcenia, a raczej z prywatnych upodobań ${ }^{45}$. Należy przy tym zaznaczyć, iż mogą one być ukształtowane w dużej mierze z przyczyn całkiem prozaicznych, np. nastrojów społecznych oraz politycznych, a także szkolnych ${ }^{46}$.

Drugi segment pytań został poświęcony kwestii samooceny wiedzy historycznej ankietowanego oraz jej źródła. Ta część składała się z dziewięciu pytań zamkniętych.

Tabela 1. Jak ocenia Pan/i swoją wiedzę historyczną?

(w skali od 1 do 5, gdzie 1 - oznacza bardzo nisko; 5 - bardzo wysoko)

\begin{tabular}{|c|c|c|c|c|c|}
\hline Ocena wiedzy (1-5) & Ocena 1 & Ocena 2 & Ocena 3 & Ocena 4 & Ocena 5 \\
\hline $\begin{array}{l}\text { Liczba odpowiedzi/ } \\
\text { Wartość procentowa }\end{array}$ & $42(1,9 \%)$ & $207(9,3 \%)$ & $698(31,3 \%)$ & $965(43,2 \%)$ & $321(14,4 \%)$ \\
\hline
\end{tabular}

Źródło: opracowanie własne.

Po zestawieniu powyższych wyników z poszczególnymi odpowiedziami dotyczącymi pytania o to, czy wykształcenie ankietowanego ma związek z naukami historycznymi, zauważalny zostaje trend wskazujący na związek między wykształceniem historycznym respondenta a wysokością jego samooceny. Szczegółowo można dostrzec to w poniższym zestawieniu.

${ }^{45}$ A. Trzoss, Cyfrowy homo ludens. Historia jako element obszaru rozrywki na portalu społecznościowym Youtube, [w:] Popularyzacja nauk historycznych - teoria i praktyka. Zbiór studiów, red. D. Gołaszewska-Rusinowska, M. Mielewska, T. Sińczak, Torun 2018, s. 193-209.

${ }^{46}$ Por.: W. Werner, Polityczność i etnocentryzm pamięci w świetle badań trendów internetowych i portali społecznościowych, [w:] Miejsca (Nie)Pamięci, Kraków 2019, s. 24-46; W. Werner, Historical Consciousness and Interest in History in Poland and Selected European Countries in the Light of Internet Data [w:] W. Werner, V. Julkowska, Contemporary Lives of the Past, Poznań 2018, s. 33-66. 
Tabela 2. Rodzaj wykształcenia respondenta w ocena własna wiedzy historycznej

\begin{tabular}{|c|c|c|c|c|c|}
\hline $\begin{array}{c}\text { Czy wykształcenie } \\
\text { ma związek z naukami } \\
\text { historycznymi? }\end{array}$ & Ocena 1 & Ocena 2 & Ocena 3 & Ocena 4 & Ocena 5 \\
\hline NIE & 39 & 189 & 567 & 646 & 164 \\
TAK & 3 & 18 & 131 & 319 & 157 \\
\hline
\end{tabular}

Źródło: opracowanie własne.

Mając na uwadze, iż co czwarty ankietowany zadeklarował brak wykształcenia okołohistorycznego, wyniki te a priori mogą wydawać się nader oczywiste. Jednakże falsyfikuje to powszechnie występujący pogląd, iż użytkownicy sieci WWW wysoko oceniają swoją wiedzę bazującą na danych tam znalezionych ${ }^{47}$. W tym przypadku weryfikacja ta wskazuje, iż mimo powszechnej dostępności informacji z dziedziny nauk historycznych w Internecie, ankietowani pozostają w sporej części zdystansowani co do stanu swojej wiedzy. Zatem można wnioskować, że albo traktują ją jako anegdotyczną (czyli taką, jaką konsumują na przykładzie badanych mediów), albo mimo wieszczonego przez Andrew Keena „,upadku autorytetu"48 użytkownicy zdają sobie sprawę z tego, iż istnieje różnica między wiedzą fachową a zdawkowymi jej elementami. Co interesujące, osoby z wyższym wykształceniem chętniej deklarują wysoką samoocenę wiedzy historycznej (289 osób ocenia ją na 4, a 122 na 5) niż w pozostałych grupach wiekowych. Tu chcielibyśmy odwołać się do wcześniej przeprowadzonych przez nas badań ${ }^{49}$, dotyczących komemoratywnego i szkolnego charakteru wyszukiwania wiedzy historycznej za pomocą przeglądarki Google. Z naszych badań wynika, iż w okresach egzaminów oraz testów, a także w czasie świąt państwowych i rocznic znacząco wzrasta zainteresowanie "szkolną wiedzą historyczną", która odpowiednio w miesiącach wakacyjnych oraz poza terminami egzaminów maleje. Potencjalnie interesującą hipotezą byłoby zweryfikowanie, czy zainteresowanie historią pośród osób z wyższym wykształceniem przekłada się na długofalowe praktykowanie tej pasji w bardziej codziennym charakterze, niezwiązanym z czynnikami edukacyjnymi i rocznicowymi. W przeprowadzanym przez nas badaniu wartym zaznaczenia jest fakt, iż równo po połowie rozłożył się procent osób z wyższym wykształceniem związanym z historią i osób nieposiadających takowego.

${ }^{47}$ A. Keen, Kult Amatora. Jak internet niszczy kulture, tłum. M. Bernatowicz, Warszawa 2007.

48 Tamże.

${ }^{49}$ W. Werner, A, Trzoss, Czy tożsamość kulturowa może być zmierzona? Badania nad mentalnościa z perspektywy Cyfrowej Humanistyki i Obliczeniowych Nauk Społecznych, [w:] Kul'turologì̌nij al'manah: Vipusk 10., red. T. I. Andruŝenko i in., Fakul'tet fillosofs'koï osvìti ì nauki Kafedra kul'turologiï ta filosofs'koï antropologiï, Winnica 2018, s. 105-118. 
W kolejnym pytaniu (wielokrotnego wyboru) ankietowani deklarowali źródła swojej wiedzy historycznej. Tu zdecydowanym faworytem (1695 odpowiedzi) były kanały Youtube o tematyce historycznej. Być może wiąże się to $\mathrm{z}$ formą, jaką reprezentuje rzeczone medium, a także z popularnością czołowych mediów historycznych (takich jak Historia bez cenzury). Na drugim miejscu znajdują się książki oraz prasa tematyczna (1504 odpowiedzi), a także wyszukiwarki/encyklopedie internetowe. Na kolejnych pozycjach znalazły się: fanpage z portalu Facebook (1159), filmy i seriale historyczne (1238), szkoła (1185) oraz instytucje kultury i muzea (1119). Najmniej popularne źródła wiedzy, jakie zostały wskazane, to portale internetowe (1033) oraz zdecydowanie mniej popularne fora internetowe (689) i gry wideo osadzone fabularnie w tematyce historyczne (799). Zważywszy na charakterystykę ankietowanych, nie dziwi miejsce szkoły w powyższym pytaniu, jednakże tym, co pozytywnie zaskakuje, jest duża liczba odpowiedzi, wskazująca na źródła drukowane stanowiące równie istotny filar wiedzy historycznej, co źródła elektroniczne. Zatem należy wykluczyć podejrzenia, iż media cyfrowe wypierają $w$ kwestii poszukiwania informacji media tradycyjne, takie jak książka czy prasa, ale stają się komplementarnym układem, z którego czerpie się informacje. Jednocześnie niskie miejsce szkoły w rankingu sugeruje, że spora część $\mathrm{z}$ ankietowanych swoją wiedzę historyczną zdobywa bądź uzupełnia samodzielnie, co szczególnie w kontekście osób poniżej osiemnastego roku życia stanowi zagrożenie poprzez wystawienie na materiały o wątpliwej wartości mery torycznej bądź dzieła pseudonaukowe.

Pytaniem pomocniczym (również wielokrotnego wyboru) było pytanie o powód wyboru danego źródła wiedzy. Najczęściej pojawiające się odpowiedzi wskazują na dwa główne powody. Pierwsze, związane z warstwą merytoryczną źródła (na kwestię osobistych zainteresowań historią wskazało 1841 ankietowanych, natomiast na prezentowaną wartość merytoryczną 1489), zdają się wskazywać na pewien stopień krytycyzmu wśród respondentów, wybierających te źródła wiedzy, które ich zdaniem są nie tylko ciekawe, ale i wartościowe. Druga grupa koncentruje się na kwestiach związanych z dostępnością (1594 odpowiedzi) źródeł oraz formą przekazu (1325). Zatem dopiero te media, cechujące się obiema powyższymi elementami, mają szansę sukcesu wśród szerszej publiczności. Wiedza ma być popularyzowana nie tylko rzetelnie, ale i w atrakcyjny sposób. Niestety, mimo zdawałoby się optymistycznego założenia, nie jest to proste zadanie do realizacji. O czym była mowa innym razem ${ }^{50}$, rozrywkowy charakter mediów i algorytmu wielkich platform premiują ten drugi czynnik. W tym wypadku respondenci deklarują, iż wybierają dane medium ze względu na popularność stosunkowo rzadko (224 osoby), nieco częściej ze względu na polecenie przez znajomych (285). Praktycznie nieistotną

${ }^{50}$ W. Werner, A. Trzoss, Czy cyfrowe media... 
rolę odgrywają przy tym wyborze reklamy (43 osoby). Jak wskażemy dalej, mimo deklarowania przez ankietowanych, iż przy swoich wyborach kierują się kwestiami merytorycznymi, a nie popularnością, to jednak forma przekazu będzie miała zdecydowane znaczenie $\mathrm{w}$ przypadku faworyzowania danego medium (przy czym - mimo oceniania danego medium przez ankietowanych jako merytoryczne - za takie uważane być nie mogą).

W drugiej części omawianego segmentu respondenci zostali zapytani o ich zwyczaje związane z korzystaniem $\mathrm{z}$ danego typu medium. W kolejnych sześciu pytaniach ankietowani odpowiadali, jak często korzystają z danego źródła wiedzy o historii. Wyniki zbiorcze prezentuje poniższa tabela:

Tabela 3. Częstotliwość użytkowania źródła wiedzy o historii

\begin{tabular}{|l|c|c|c|c|c|c|}
\hline & $\begin{array}{c}\text { Portale } \\
\text { inter- } \\
\text { netowe }\end{array}$ & $\begin{array}{c}\text { Fanpage } \\
\text { na Face- } \\
\text { booku }\end{array}$ & $\begin{array}{c}\text { Fora } \\
\text { inter- } \\
\text { netowe }\end{array}$ & $\begin{array}{c}\text { Kanały } \\
\text { na } \\
\text { Youtube }\end{array}$ & $\begin{array}{c}\text { Filmy } \\
\text { i seriale }\end{array}$ & $\begin{array}{c}\text { Gry } \\
\text { wideo }\end{array}$ \\
\hline Codziennie & 500 & 655 & 211 & 336 & 78 & 237 \\
$(22,4 \%)$ & $(29,3 \%)$ & $(9,4 \%)$ & $(15 \%)$ & $(3,5 \%)$ & $(10,6 \%)$ \\
\hline Kilka razy & 765 & 680 & 396 & 833 & 328 & 446 \\
w tygodniu & $(34,3 \%)$ & $(30,5 \%)$ & $(17,7 \%)$ & $(37,3 \%)$ & $(14,7 \%)$ & $(20 \%)$ \\
\hline Raz na tydzień & 361 & 266 & 260 & 487 & 469 & 293 \\
& $(16,2 \%)$ & $(11,9 \%)$ & $(11,6 \%)$ & $(21,8 \%)$ & $(21 \%)$ & $(13,1 \%)$ \\
\hline Raz w miesiącu & 195 & 105 & 271 & 207 & 570 & 213 \\
& $(8,7 \%)$ & $(4,7 \%)$ & $(12,1 \%)$ & $(9,3 \%)$ & $(25,5 \%)$ & $(9,5 \%)$ \\
\hline Rzadziej niż & 172 & 158 & 376 & 215 & 532 & 358 \\
raz w miesiącu & $(7,7 \%)$ & $(7,1 \%)$ & $(16,8 \%)$ & $(9,6 \%)$ & $(23,8 \%)$ & $(16 \%)$ \\
\hline Nie dotyczy & 240 & 369 & 719 & 155 & 256 & 686 \\
& $(10,7 \%)$ & $(16,5 \%)$ & $(32,2 \%)$ & $(6,9 \%)$ & $(11,5 \%)$ & $(30,7 \%)$ \\
\hline
\end{tabular}

Źródło: opracowanie własne.

Zauważalny jest rozdźwięk między mediami internetowymi a filmami, serialami oraz grami wideo. Oczywiście, wzięte pod uwagę zostało to, jak często dane medium się ukazuje, co zdaje się współgrać z otrzymanymi wynikami. Wysokiej częstotliwości pojawiania się materiałów popularyzujących wiedzę historyczną towarzyszy wysoka częstotliwość partycypacji w odbiorze tychże treści. Podobnie sprawa ma się $\mathrm{w}$ ramach samych mediów cyfrowych - media społecznościowe, Youtube i Facebook, dominują nad portalami i forami; nawet więcej, Facebook z racji prostoty mechanizmów przekazu i tworzenia treści zdaje się mieć nieznaczną przewagę nad platformą wideo, gdzie w końcu przygotowanie pełnowartościowej produkcji filmowej zajmuje więcej czasu. Nie musi od razu oznaczać to większej siły oddziaływania mediów społecznościowych w sferze funkcjonowania wiedzy historycznej, niemniej jednak wysoka częstotliwość użytkowania danego medium może być 
istotnym elementem wspomagającym budowanie stałej grupy odbiorców, a zatem bardziej zaangażowanej, i mieć wpływ przez to na wzrost jego popularności. Jak można zauważyć w badaniu, nie został uwzględniony należący do spółki Facebook portal Instagram. Porównując zainteresowanie historią na Instagramie z innymi mediami, nietrudno spostrzec, iż dzieli je ogromna przepaść nie tylko w zakresie liczby twórców, ale i odbiorców. Jest to kwestia rozwojowa, której z pewnością warto się przyjrzeć, zwłaszcza biorąc pod uwage zauważone przy innej okazji przez nas wnioski dotyczące „wizualności” $\mathrm{w}$ partycypacji w medium ${ }^{51}$. W przeciwieństwie do innych omawianych w niniejszym artykule mediów, portale społecznościowe, z uwagi na znacznie większą ilość pojawiających się na ich informacji, a niekiedy również ich formę (Facebook), mają mniejszą zdolność do wytworzenia postu bądź filmu popularnego w dłuższej perspektywie czasowej, gdyż aktywność użytkowników w stosunku do nich często ogranicza się jedynie do tu i teraz, gdy tymczasem do popularnych filmów i seriali niejednokrotnie powraca się wiele razy.

W segmencie trzecim ankietowani zostali zapytani o ich własne preferencje wobec piętnastu przywołanych przez mediów (kanałów, fanpage'ów). Po pierwsze - respondenci zostali zapytani o znajomość mediów. Aby lepiej zobrazować odpowiedzi, uwzględniliśmy odpowiedzi z podziałem na kategorie wiekowe ${ }^{52}$.

Kwestię interpretacji takiego stanu rzeczy poruszyliśmy już wcześniej ${ }^{53}$. Tu jednak chcielibyśmy podkreślić korelację pomiędzy znajomością danego medium a formą przekazywanych przez nie treści. Jeśli zestawić to z dokonującą się przemianą pokoleniową w zainteresowaniach, widoczną w powyższej tabeli, można zasugerować wniosek, iż czynnikiem znacznie determinującym popularność przekazu jest kwestia oprawy wizualnej oraz stosowania dozy kontrowersyjności (tabloidyzacji) w treści. Kwestia fachowości i hermetyczności tematu znacząco rysuje się w przypadku tych profili, które znane są częściej w grupach osób powyżej 26. roku życia. Interpretację taką warto zestawić z późniejszym wykresem, opartym na tzw. mutual information, w stosunku do pytania o ocenę w skali od 1 do 5 omawianych profili, o czym dalej. Kontynuując wątek popularności, można zauważyć, iż ankietowani często wskazywali na te media, które pojawiają się na więcej niż jednej platformie, a im ich więcej, tym lepiej dla wyniku. Zatem im większa multiplatfor-

51 W. Werner, D. Gralik, A. Trzoss, Wiedza historyczna w świecie cyfrowym. Funkcjonowanie, problemy, wymiana pokoleniowa, [w:] Historia a media. Zbiór studiów, t. 4, red. D. Gołaszewska-Rusinowska, M. Mielewska, Toruń 2019, s. 120-141.

52 Z wyjątkiem kategorii 65+ ze względu na nieistotną statystycznie liczbę respondentów (sześć osób).

${ }^{53}$ W. Werner, D. Gralik, A. Trzoss, dz. cyt. 
Tabela 4. Znajomość profilu w danej grupie wiekowej

\begin{tabular}{|c|c|c|c|c|c|c|c|c|}
\hline Grupa wiekowa & \multicolumn{2}{|c|}{ Mniej niż 19} & \multicolumn{2}{|c|}{$19-25$} & \multicolumn{2}{|c|}{$26-40$} & \multicolumn{2}{|c|}{$41-65$} \\
\hline $\begin{array}{l}\text { Liczba osób } \\
\text { danei orupie }\end{array}$ & \multicolumn{2}{|c|}{924} & \multicolumn{2}{|c|}{757} & \multicolumn{2}{|c|}{436} & \multicolumn{2}{|c|}{110} \\
\hline $\begin{array}{l}\text { Czy dany fan- } \\
\text { page jest znany? }\end{array}$ & NIE & TAK & NIE & TAK & NIE & TAK & NIE & TAK \\
\hline $\begin{array}{l}\text { Ciekawostki hi- } \\
\text { storyczne }\end{array}$ & 399 & 525 & 245 & 512 & 131 & 305 & 38 & 72 \\
\hline Histmag & 665 & 259 & 421 & 336 & 133 & 303 & 28 & 82 \\
\hline Historia.org & 639 & 285 & 520 & 307 & 190 & 246 & 48 & 62 \\
\hline $\begin{array}{l}\text { Historia } \\
\text { bez cenzury }\end{array}$ & 50 & 874 & 42 & 715 & 65 & 371 & 39 & 71 \\
\hline $\begin{array}{l}\text { Historia } \\
\text { i wojskowość }\end{array}$ & 765 & 159 & 628 & 129 & 384 & 52 & 101 & 9 \\
\hline $\begin{array}{l}\text { Historia } \\
\text { w } 5 \text { minut }\end{array}$ & 147 & 777 & 151 & 606 & 207 & 229 & 91 & 19 \\
\hline Historycy.org & 705 & 219 & 405 & 292 & 198 & 238 & 45 & 65 \\
\hline $\begin{array}{l}\text { Historyczne } \\
\text { Bzdury }\end{array}$ & 783 & 141 & 591 & 166 & 307 & 129 & 84 & 26 \\
\hline Historykon & 798 & 126 & 561 & 196 & 288 & 148 & 68 & 42 \\
\hline $\begin{array}{l}\text { Tytus } \\
\text { (Tytus.edu) }\end{array}$ & 884 & 40 & 730 & 27 & 412 & 24 & 95 & 19 \\
\hline $\begin{array}{l}\text { II wojna } \\
\text { światowa } \\
\text { w kolorze }\end{array}$ & 521 & 403 & 378 & 379 & 242 & 194 & 71 & 39 \\
\hline Napoleon.org & 856 & 68 & 687 & 70 & 392 & 44 & 91 & 19 \\
\hline Ohistorie & 874 & 50 & 730 & 27 & 406 & 30 & 92 & 18 \\
\hline $\begin{array}{l}\text { Sigillum } \\
\text { Authenticum }\end{array}$ & 859 & 65 & 635 & 122 & 299 & 137 & 73 & 37 \\
\hline ThrashingMad & 398 & 526 & 382 & 375 & 305 & 131 & 99 & 11 \\
\hline
\end{tabular}

Źródło: opracowanie własne.

m ow o śćc ${ }^{4}$, tym większy zasięg społeczny danego medium, co zwiększa pośrednio zaangażowanie subskrybentów.

W kolejnym pytaniu ankietowani zostali zapytani o to, czy angażują się w społeczność któregokolwiek z wymienionych wyżej mediów, np. poprzez zamieszczanie postów, komentowanie, lajkowanie czy udostępnianie treści. Aż 37,4 proc. $z$ nich odpowiedziało negatywnie (835 odpowiedzi), co oczy-

${ }^{54}$ To jest na im większej liczbie platform, kanałów komunikacji dany profil/medium występuje. 
wiście nie wyklucza śledzenia tychże treści. Kolejne 117 osób (5,2 proc.) podało, iż kwestia ta ich nie dotyczy (co wskazuje na brak znajomości omawianych mediów). Pozostałe 58 proc. ankietowanych w mniejszym lub większym stopniu tworzy community (społeczność) wokół fanpage'ów, stron, forów. Regularnie angażuje się co dziesiąty ankietowany (237 osób), czasami aż jedna czwarta (554), a sporadycznie jedna piąta (490). Media społecznościowe kierują się podstawową zasadą angażowania swoich użytkowników w twórczość w nich funkcjonującą, co przekłada się oczywiście na obieg wiedzy historycznej ${ }^{55}$.

W trzech następnych pytaniach ankietowani odpowiadali, czy decydując się na obejrzenie filmu lub serialu, a także angażowanie (m.in. poprzez subskrypcję) w fanpage czy kanały Youtube oraz gry wideo, zwracają uwagę na ich osadzenie w przeszłości i tematykę historyczną.

Tabela 5. Częstotliwość korzystania z rodzaju medium

\begin{tabular}{|l|l|l|l|}
\hline \multicolumn{1}{|c|}{ Częstotliwość } & Filmy i seriale & $\begin{array}{c}\text { Facebook oraz } \\
\text { Youtube }\end{array}$ & Gry wideo \\
\hline Zawsze & $441(19,7 \%)$ & $382(17,1 \%)$ & $224(10 \%)$ \\
Często & $849(38 \%)$ & $833(37,3 \%)$ & $501(22,4 \%)$ \\
Czasami & $552(24,7 \%)$ & $555(24,9 \%)$ & $440(19,7 \%)$ \\
Rzadko & $183(8,2 \%)$ & $193(8,6 \%)$ & $249(11,2 \%)$ \\
Wcale & $102(4,6 \%)$ & $143(6,4 \%)$ & $192(8,6 \%)$ \\
Nie dotyczy & $106(4,7 \%)$ & $127(5,7 \%)$ & $627(28,1 \%)$ \\
\hline
\end{tabular}

Źródło: opracowanie własne.

Wyniki z pierwszych dwóch kolumn zdają się sugerować, iż ankietowani zdecydowanie zwracają uwagę na rzeczone produkcje, a nie dokonują jedynie ich biernej konsumpcji (w zasadzie prosumpcji). Jednak za Janem Pomorskim powtórzmy istotne pytania. Czy taki ogląd sytuacji przez respondentów jest krytyczny ${ }^{56}$ ? Czy zwracanie uwagi na "detale historyczne" nie ma charakteru faktograficznego, w którym akcent kładzie się na "zgodność z minioną przeszłością", natomiast mniej na procesy historyczne? W przypadku portali społecznościowych zaś - czy nie jest aby tak, iż popularne portale, serwując treści historyczne, faktograficznie zorientowane, kierują się zwyczajnie mechanizmem podaż-popyt? Czy społeczne uwarunkowanie nie wynika ze szkolnego uformowania wizji historii, jak pisze Pomorski? Problem jest istotny o tyle, iż jak wynika z jednego z ostatnich pytań, ledwie połowa respondentów we-

\footnotetext{
${ }^{55} \mathrm{~W}$. Werner, A. Trzoss, Czy cyfrowe media...

${ }^{56}$ J. Pomorski, dz. cyt.
} 
ryfikuje treści przez siebie absorbowane. Zatem wybór danych treści może się wiązać z prywatnymi zainteresowaniami, które znajdują potwierdzenie $\mathrm{w}$ partycypowanym medium. Pośrednio można to interpretować, iż wiedza historyczna tam przedstawiona nie odgrywa w oczach odbiorców pierwotnie roli edukacyjnej, a bardziej rozrywki, dobrej opowieści.

Seria kolejnych czterech pytań miała charakter otwarty, dotyczyły one odpowiednio: zagadnienia historycznego, dla którego respondenci chcieliby sfinansować wysokobudżetową produkcję, jeśli mieliby taką możliwość, a także wskazania najlepszego, pod względem przedstawienia historii, kolejno: filmu, serialu oraz gry wideo. Ze względu na fakt, iż wszystkie wymienione wyżej pytania były dla wypełniających ankietę nieobowiązkowe (brak odpowiedzi nie uniemożliwiał wysłania ankiety), liczba odpowiedzi różni się od ogólnej liczby respondentów. Wyniki dla pierwszego z podanych wyżej pytań kształtują się następująco:

Tabela 6. Odpowiedzi na pytanie:

Gdyby Pan/i mógł/a sfinansować wysokobudżetową produkcję historyczną, jakiego okresu/ wydarzeniu/postaci by ona dotyczyła?

\begin{tabular}{|l|c|}
\hline \multicolumn{1}{|c|}{ Epoka } & Liczba odpowiedzi \\
\hline II wojna światowa (1939-1945) & 325 \\
Historia powszechna średniowiecza (476-1492) & 284 \\
Historia powszechna nowożytna (1492-1789) & 215 \\
Czasy Rzeczypospolitej Obojga Narodów (1569-1795) & 212 \\
Historia antyku (starożytna Grecja i Rzym) & 167 \\
Historia powszechna XIX w. (1815-1914) & 147 \\
Polska okresu piastowskiego & 125 \\
Dwudziestolecie międzywojenne na świecie (1918-1939) & 109 \\
I wojna światowa (1914-1918) & 100 \\
Okres II Rzeczypospolitej (1918-1939) & 90 \\
Okres zimnej wojny (1945-1989) & 77 \\
Rewolucja francuska i epoka napoleońska (1789-1815) & 74 \\
Polska pod panowaniem Jagiellonów & 64 \\
Historia ziem polskich w XIX w. (1815-1914) & 57 \\
Czasy Polskiej Rzeczypospolitej Ludowej (1945-1989) & 41 \\
Historia starożytnego Bliskiego Wschodu (Mezopotamia, Egipt) & 39 \\
Historia najnowsza (po 1989 r.) & 35 \\
Prahistoria & 28 \\
\hline
\end{tabular}

Źródło: opracowanie własne. 
W zakresie postaci historycznych najwięcej głosów zebrali: Napoleon Bonaparte (19 głosów), rotmistrz Witold Pilecki (14), Bolesław Chrobry (13), marszałek Józef Piłsudski i Tadeusz Kościuszko (po 10), Roman Dmowski i Zawisza Czarny (po 8) oraz Aleksander III Wielki i Kazimierz III Wielki $(\text { po } 7)^{57}$.

Przedstawiając powyższe wyniki, należy zaznaczyć dość szerokie spektrum udzielanych odpowiedzi, co też wymusiło dokonanie ich kategoryzacji, przy czym zdecydowaliśmy się na podział pod względem epok i postaci. Uzupełniając te dane, można dodać, że wiele odpowiedzi miało charakter ogólnikowy - respondenci wskazali jedynie nazwę okresu historycznego. W takim przypadku przyporządkowano odpowiedzi do dziejów powszechnych danej epoki (w stosunku do średniowiecza i epok powszechnych). W przesłanych ankietach znalazły się również tematy przekrojowe, które dotykają wielu epok. Wśród najczęściej pojawiających się można wymienić zagadnienia związane z historią wojskowości, historią gospodarczą, historią kobiet oraz historią życia codziennego.

Przedstawione wyżej rezultaty częściowo pokrywają się z wynikami kolejnych pytań. Wśród filmów ${ }^{58}$ najczęściej wskazywanym tytułem był Szeregowiec Ryan, który zebrał 116 głosów. W pierwszej dziesiątce znalazły się również kolejno: Pianista (82 głosy), Potop (66), Ogniem i mieczem (62), Dunkierka (50), Wotyń (47), Miasto 44, Królestwo niebieskie, Krzyżacy (po 32) oraz Upadek $(31)^{59}$. W kategorii seriali grupę najczęściej wskazywanych produkcji są: Kompania braci (176 głosów), Wikingowie (135), Rzym (85), Czas honoru (83), The Crown (53), Korona królów (52), Pacyfik (34), Wspaniałe stulecie (33), Dynastia Tudorów (26), Czterej pancerni i pies, Gra o Tron oraz The Last Kingdom (po 18) ${ }^{60}$. Z kolei wśród gier topową dziesiątkę serii i tytułów ${ }^{61}$ stanowią: seria Europa Universalis (220 głosów), Kingdom Come Deliverance (196), seria Total War (118), seria Hearts of Iron (113), Crusader Kings II (111), seria Assassin's Creed (81), seria Call of Duty (50), seria Battlefield (39), seria Company of Heroes (24) i seria Civilization $(23)^{62}$.

Analizując całość odpowiedzi na pytania otwarte, można zauważyć kilka prawidłowości. Przede wszystkim wskazane filmy, seriale oraz gry wideo $\mathrm{w}$ dużej mierze pokrywają się z epokami, na temat których respondenci chcieliby sfinansować wysokobudżetową produkcję. Prawdopodobnie są

${ }^{57}$ Ogółem w zakresie postaci wskazano 184 osoby reprezentujące różne epoki historyczne.

${ }^{58}$ Zarówno w zakresie filmów, jak i seriali wzięto pod uwagę jedynie produkcje fabularne, nie uwzględniono również odpowiedzi, w których nie wskazano konkretnych tytułów.

${ }^{59}$ Łącznie wskazano 261 filmów.

${ }^{60}$ Łącznie wymieniono 125 seriali.

${ }^{61}$ Ze względu na częste wskazywanie przez respondentów ogólnych odpowiedzi (tytuł gry bez numeru/wskazanie serii) zdecydowano się podsumować głosy dla konkretnych serii gier.

62 Łącznie wskazano 66 gier/serii gier. 
to jednocześnie ulubione epoki i postacie historyczne badanych. Co ciekawe, wśród wskazanych dzieł audiowizualnych można zauważyć dwie główne grupy, tj. produkcje, które w pewnym wymiarze można uznać za kultowe (Szeregowiec Ryan wśród filmów, Kompania braci wśród seriali, seria Europa Universalis wśród gier), a także dzieła stosunkowo nowe, cieszące się popularnością wśród polskich widzów i graczy (Dunkierka, Wikingowie, Kingdom Come).

W stosunku do pierwszej z wymienionych kategorii, ze względu na wysoki poziom wykonania (efekty specjalne, spektakularne sceny batalistyczne itp.), co jednak nie zawsze współgra z poprawnością faktograficzną, i idącą $\mathrm{z}$ tym parze dobrą renomę, można mówić o nie mniejszym niż w przypadku social mediów wpływie na wiedzę historyczną respondentów. Za wyjątek w tej grupie można uznać filmy i seriale powstałe przed 1989 r., których popularność, prawdopodobnie szczególnie wśród starszych respondentów, można tłumaczyć małą liczbą audiowizualnych dzieł historycznych, które jednakże były szeroko kolportowane zarówno przez władze komunistyczne, jak i 1989 r., np. poprzez wielokrotne emisje w telewizji.

Interesujące jest również wskazanie jako produkcji o wysokich walorach pod względem historycznym dzieł z kategorii fantasy (szczególnie Gry o Tron), co można interpretować jako przejaw niewielkiej wiedzy respondentów na temat epoki, do której te dzieła nawiązują, lub też jej wyobrażenia przez respondentów niezgodnie ze stanem współczesnych badań. Po części koreluje to z przedstawionymi niżej wynikami pytań dotyczącymi weryfikacji treści, dowodzi też umiejętności kreowania wizji świata przez ich twórców.

W jednym z ostatnich pytań ankietowani odpowiadali, jak oceniają poziom merytoryczny omawianych fanpage'ów oraz kanałów na Youtube (w skali od 1 do 5; pytanie nie było obligatoryjne). Powyższy wykres obrazuje znormalizowaną informację wzajemną (ang. mutual information) pomiędzy rozkładami ocen poszczególnych par mediów. Wartości bliskie 1 świadczą o dużej korelacji pomiędzy rozkładami ocen, natomiast bliskie 0 - o niezależności rozkładów ocen. Przykładowo, w przypadku pary Historia.org.pl i Histmag.org podana wartość oznacza, że oceniający je respondenci głosowali podobnie. Innymi słowy, znając wyniki dla jednego z portali (np. Historia.org.pl), jesteśmy w stanie z dużą skutecznością przewidzieć, jak zostanie oceniony drugi. Z kolei rozpatrując kanał Historia bez cenzury, gdzie wartości informacji wzajemnej $z$ innymi portalami nie przekraczały wartości 0.5 , nie jesteśmy w stanie stwierdzić jakiejkolwiek korelacji. Znając wyniki ocen tego portalu, nie możemy praktycznie nic powiedzieć o pozostałych ocenach.

W kwestii interpretacji skazani jesteśmy na gamę domysłów osadzoną w kontekście literatury oraz samej ankiety. Hipoteza, którą stawiamy, opiera się na dwóch przesłankach: grup docelowych odbiorców oraz formy i tre- 


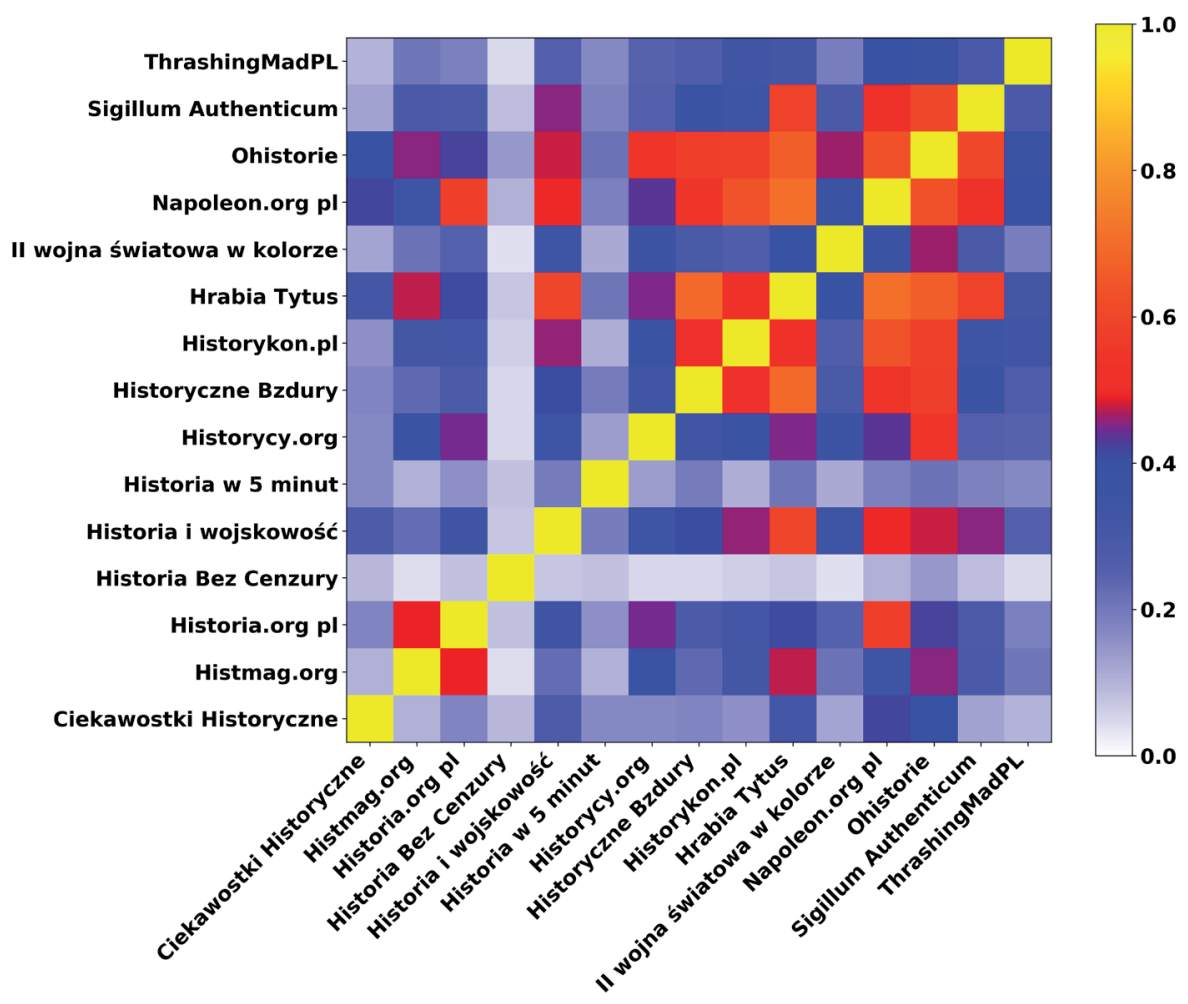

Wykres 1. Znormalizowana informacja wzajemna rozkładu ocen poszczególnych par profili. Źródło: opracowanie własne.

ści prezentowanych przez omawiane media. $W$ ramach takiej koncepcji oceny Historii bez cenzury nie korelują z innymi podmiotami ze względu na bardzo zróżnicowane, a także niezwykle liczne środowisko subskrybentów, które nierzadko nie śledzi innych treści, oraz szerokie spektrum prezentowanych tematów i treści. Para omawiana w przykładzie Histmag i Historia. org cechuje się podobną formą, tematyką oraz środowiskiem subskrybentów. Podobnie sprawa ma się w grupie złożonej z: Sigillum Authenticum, Ohistorie, Napoleon.org.pl, Hrabia Tytus, Historykon i Historyczne Bzdury. Grupa ta składa się z mediów o wysokim podobieństwie rozkładów ocen. Mimo różnej tematyki wszystkie z nich cechują się wysokim stopniem wyspecjalizowania tematycznego, fachowością prezentowanych informacji oraz brakiem kontrowersyjności i nieprzesadną warstwą formy wizualnej. Można się zatem pokusić (w oparciu także o partykularne wyniki ankiety, dotyczące m.in. wcześniejszych pytań o znajomość danych profili) o próbę określenia typowego subskrybenta tychże profili. Taką osobą jest student historii z dużego miasta, który chętnie i często angażuje się w wymienione media. Jak już zostało przez 


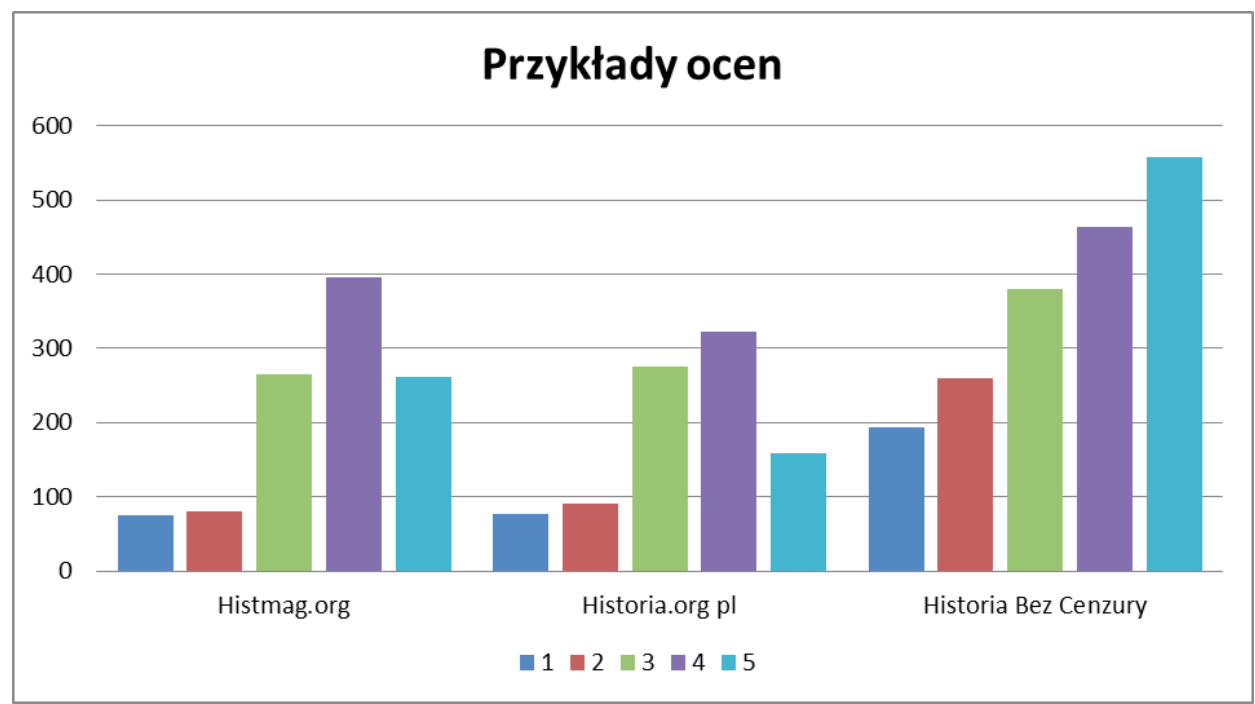

Wykres 2. Przykładowy rozkład ocen profili.

Źródło: opracowanie własne.

nas zaznaczone wcześniej, niemal 56,7 proc. ankietowanych weryfikuje treści zastane w powyższych mediach. Następnie, w pytaniu o charakterze otwartym, ankietowani wskazali, w jaki sposób głównie dokonują weryfikacji treści historycznych. Tu również zauważalna jest istotna rola źródeł internetowych, które, jak podejrzewamy, cieszą się takim zainteresowaniem ze względu na wszechobecność, prostotę dostępu oraz swego rodzaju kompaktowość informacji.

W ostatnim segmencie respondenci zostali zapytani o kwestie związane z polityką historyczną. W przedostatnim pytaniu ankiety 53,6 proc. (1196) odpowiedzi wskazywało, iż państwo polskie powinno wspierać inicjatywy związane z polityką historyczną skierowane do poszczególnych grup społecznych. 32 proc. (715) wskazało raczej tak, a zatem istnieje spore oczekiwanie społeczne na państwowe wsparcie $w$ tej materii. $Z$ drugiej strony, $w$ ostatnim pytaniu zawartym $\mathrm{w}$ formularzu wyniki są bardziej zdywersyfikowane. Ankietowani byli pytani, czy informacja o wsparciu przez państwo powstania danej treści o tematyce historycznej wpływa na jej odbiór u respondenta (przy czym nie był rozróżniany stosunek pozytywny i negatywny). 21,3 proc. (476) zaznaczyło, iż ta informacja jest dla nich zdecydowanie istotna, a w przypadku 36,7 proc. (819) raczej tak. Niezainteresowani tą kwestią stanowią 32,6 proc. ankietowanych (572 osoby raczej nie, 157 zdecydowanie nie). 9,4 proc. respondentów nie ma zdania w tej materii (209 ankietowanych). Z jednej strony istnieje $\mathrm{w}$ społeczeństwie aprobata dla państwowego wsparcia inicjatyw o tematyce historycznej, z drugiej - nie ma to aż tak zdecydowanego przełożenia 
Tabela 7. Źródła weryfikacji informacji

\begin{tabular}{|l|c|}
\hline Książki/literatura & 429 \\
Internet & 425 \\
Prace/czasopisma naukowe & 352 \\
Wikipedia & 293 \\
Rozmowy ze znajomymi i rodziną, wiedza nauczycieli/ & 81 \\
wykładowców/fachowców & \\
Wiedza własna/własne badania & 74 \\
Źródła historyczne & 55 \\
Filmy dokumentalne & 7 \\
Muzea & 6 \\
Próba krzyżowa & 2 \\
Telewizja & 2 \\
Gry & 1 \\
Literatura pseudonaukowa & 1 \\
\hline
\end{tabular}

Źródło: opracowanie własne.

na odbiór (zarówno pozytywny, jak i negatywny) tych działań. Można próbować założyć, iż respondenci rozróżniają te inicjatywy podszyte propagandą obecną w polityce historycznej oraz te, które otrzymały państwowe wsparcie (zapewne zwłaszcza te finansowe), ale są pod egidą fachowców, co do których - wydaje się - jest nieco większe zaufanie społeczne. Możliwe też, że spora grupa respondentów zdaje sobie sprawę z charakterystycznego dla naszego kraju modelu finansowania produkcji filmowych, gdzie głównym mecenasem wielu obrazów jest Polski Instytut Sztuki Filmowej oraz spółki skarbu państwa, co z jednej strony umożliwia powstanie nowych dzieł o tematyce historycznej, z drugiej zaś - gwarantuje je na niewystarczającym poziomie, co $\mathrm{w}$ połączeniu $\mathrm{z}$ często słabym wykonaniem powoduje ich krytyczny odbiór przez widownię, zwłaszcza w porównaniu z zachodnimi blockbusterami, które cieszą się w Polsce popularnością chociażby w segmencie kina wojennego.

Zrelacjonowane powyżej badania mogą rzucić światło na funkcjonowanie $\mathrm{w}$ Polsce sfery świadomości historycznej, nazywanej w światowym piśmiennictwie public history ${ }^{63}$, który to termin wiąże się z zjawiskiem społecznego zapotrzebowania na wiedzę historyczną. Zapotrzebowania, które może, ale bynajmniej nie musi być zaspokajane przez wytwory profesjonalnej historiografii. W omawianym przypadku zauważalna jest silna potrzeba narracji,

${ }^{63}$ H. Kean, P. Ashton, Introduction: People and their Pasts and Public History Today, [w:] People and Their Pasts Public History Today, red. P. Ashton, H. Kean, Palgrave Macmillan 2009, s. 1-20. 
która oprócz realizowania tradycyjnych funkcji związanych z wiedzą historyczną (np. podtrzymywania pozytywnej tożsamości narodowej) znacząco akcentuje potrzebę emocjonalnego zaangażowania w przeżywanie ludzkich dramatów obecnych w dziejach, oderwania od codziennej rzeczywistości, poczucia czegoś wyjątkowego - w skrócie można to określić jako potrzebę rozrywki opartej na przeżywaniu niecodziennej realności.

\section{Bibliografia}

Ashton P., Kean H., People and Their Pasts Public History Today, Palgrave Macmillan 2009.

Assorodobraj N., "Żywa historia”. Świadomość historyczna: symptomy i propozycje badawcze, "Studia Socjologiczne" 1963, nr 2, s. 5-45.

Bolter J.D., Grusin R., Remediation. Understanding New Media, MIT Press 1999.

Bożewicz M., Świadomość historyczna Polaków, „Komunikat z Badań” 2016, nr 68, CBOS.

Brexit: The Uncivil War, reż. T. Haynes, 7 stycznia 2019.

Burgess J., Green J., Youtube: wideo online a kultura uczestnictwa, tłum. T. Płudowski, Warszawa 2011.

Cadwalladr C., The Great British Brexit Robbery: How Our Democracy Was Hijacked, "Guardian”, 7 maja 2017, https:/ / www.theguardian.com/technology/2017/may/07/the-great-britishbrexit-robbery-hijacked-democracy (dostęp: 21.09.2019).

Clement J., Most Popular Social Networks Worldwide as of July 2019, https:/ / www.statista.com/ statistics/272014/global-social-networks-ranked-by-number-of-users/ (dostęp: 21.09.2019).

Filiciak M., Internet - społeczne metamedium, [w:] Media audiowizualne, red. W. Godzic, Warszawa 2010, s. 104-124.

Formularz ankiet google: https://docs.google.com/forms/u/0/ (dostęp: 21.09.2019).

Gralik D., Wptyw gier wideo na wiedzę historyczna i popularyzację historii, [w:] Popularyzacja nauk historycznych - teoria i praktyka. Zbiór studiów, red. D. Gołaszewska-Rusinowska, M. Mielewska, T. Sińczak, Torun 2018 s. 181-192.

Raport Polacy wobec historii - zainteresowanie a wiedza, http:/ / www.tnsglobal.pl/archiwumraportow/2014/04/04/polacy-wobec-historii-zainteresowanie-a-wiedza/ (dostęp: 21.09.2019).

Strona Ciekawostki historyczne, https://www.facebook.com/ciekawostkihistoryczne/ (dostęp: 15.05.2019).

Strona Histmag.org, https:/ / www.facebook.com/histmag.org/?ref=br_rs (dostęp: 15.05.2019).

Strona Historia i wojskowość - wszystko czego mógłbyś nie wiedzieć, https:/ / www.facebook.com/ Historia-i-wojskowo \% C5\%9B\%C4\%87-wszystko-czego-m\%C3\%B3g\%C5\%82by \% C5\%9Bnie-wiedzie\%C4\%87-1710778358946910/ (dostęp: 15.05.2019).

Strona Historia bez cenzury, https://www.facebook.com/historiabezcenzury/ (dostęp: 15.05. 2019).

Strona Historia.org.pl, https://www.facebook.com/historiaorgpl/?ref=br_rs (dostęp 15.05. 2019).

Strona Historia w 5 minut, https:/ / www.facebook.com/historiaw5minut/ (dostęp: 15.05.2019).

Strona Historycy.org, https://www.facebook.com/historycy/ (dostęp: 15.05.2019).

Strona Historyczne Bzdury, https://www.facebook.com/historycznebzdury/ (dostęp: 15.05. 2019).

Strona Historykon, https://www.facebook.com/historykon/?ref=br_rs (dostęp: 15.05.2019).

Strona Hrabia Tytus, https:/ / www.facebook.com/Hr.Tytus/ (dostęp: 15.05.2019). 
Strona Napoleon.org.pl, https://www.facebook.com/napoleonorgpl/?ref=br_rs (dostęp: 15.05. 2019).

Strona Ohistorie, https://www.facebook.com/ohistorie/ (dostęp: 15.05.2019).

Strona Sigillum Authenticum, https://www.facebook.com/sigillum.authenticum/?ref=br_rs (dostęp: 15.05.2019).

Strona Thrashingmadpl, https://www.facebook.com/Thrashingmadpl-248440875304443/ (dostęp: 15.05.2019).

Strona II wojna światowa w kolorze, https://www.facebook.com/WojnawKolorze/?ref=br_rs (dostęp: 15.05.2019).

Keen A., Kult Amatora. Jak internet niszczy kulture, tł. M. Bernatowicz, Warszawa 2007.

Kosinski M., Matz S.C., Gosling S.D., Popov V., Stillwell D.J., Facebook as a Research Tool for the Social Sciences: Opportunities, Challenges, Ethical Considerations and Practical Guidelines, „American Psychologist” 2015, vol. 70, Issue 6, s. 543-556.

Litwic-Kaminska K., Kultura obrazkowa w dydaktyce - szanse i zagrożenia, „Forum Dydaktyczne” 2011, nr 7-8, s. 177-188.

MacLuhan M., Understanding Media. The Extensions of Man, London-New York 1964.

Manovich L., Software Takes Command: Extending the Language of New Media, New York 2013.

Matz S.C., Kosinski M., Nave G., Stillwell D.J., Psychological Targeting as an Effective Approach to Digial Mass Persuasion, "Proceedings of the National Academy of Sciences of the United States of America" 2017, vol. 114, Issue 48, s. 12714-12719.

Michalski Ł., Kilka uwag o mitach na temat świadomości historycznej Polaków, [w:] Historycy i politycy: polityka pamięci w III RP, red. P. Skibiński, T. Wiścicki, M. Wysocki, Warszawa 2011, s. 193-209.

Pomorski J., Jakiej historiografii Polacy dzisiaj potrzebują?, [w:] Spogladając w przeszłość. Studia i szkice metahistoryczne, red. J. Pomorski, Lublin 2017, s. 29-51.

Pomorski J., Przyszli historycy o historii. Z badań nad świadomościa historyczną Polaków w latach 1987-1988, [w:] Spogladając w przeszłość. Studia i szkice metahistoryczne, red. J. Pomorski, Lublin 2017, s. 53-87.

Prosumpcja: pomiędzy podejściem apokaliptycznych a emancypujacym, red. P. Siuda, T. Żaglewski, Gdańsk 2014.

Przeszłość jako przedmiot zainteresowań $i$ dyskusji we wspótczesnym społeczeństwie polskim, CBOS 1988.

Rulka J., Przemiany świadomości historycznej młodzieży, Bydgoszcz 1991.

Sartori G., Homo videns: telewizja i post-myślenie, przekł. J. Uszyński, Warszawa 2005.

Sayer F., Public History. A Practical Guide, Bloomsbury 2019.

Sunstein C., \#Republic: Divided democracy in the age of social media, Princeton University Press 2017.

Szacka B., Świadomość historyczna (Wnioski z badań empirycznych), „Studia Socjologiczne” 2011, nr 1(200), s. 233-260; oryginał: „Studia Socjologiczne” 1977, nr 3(66), s. 66-103.

The Great Hack, reż. K. Amer, J. Noujaim, 26 stycznia 2019.

Trzoss A., Cyfrowy homo ludens. Historia jako element obszaru rozrywki na portalu społecznościowym Youtube, [w:] Popularyzacja nauk historycznych - teoria i praktyka. Zbiór studiów, red. D. Gołaszewska-Rusinowska, M. Mielewska, T. Sińczak, Torun 2018, s. 193-209.

Tufekci Z., Facebook's Surveillance Machine, "The New York Times” 19 marca 2018, https:/ / www. nytimes.com/2018/03/19/opinion/facebook-cambridge-analytica.html (dostęp: 21.09.2019).

Werner W., Gralik D., Trzoss A., Wiedza historyczna w świecie cyfrowym. Funkcjonowanie, problemy, wymiana pokoleniowa, [w:] Historia a media. Zbiór studiów, t. 4, red. D. Gołaszewska-Rusinowska, M. Mielewska, Toruń 2019, s. 120-141.

Werner W., Polityczność i etnocentryzm pamięci w świetle badań trendów internetowych i portali spotecznościowych, [w:] Miejsca (Nie)Pamięci, red. D. Strojnowska, Kraków 2019, s. 24-46. 
Werner W., Trzoss A., Czy cyfrowe media wywotuja społeczna paranoję? Dwugłos w sprawie obecności teorii spiskowych w mediach społecznościowych i kulturze masowej, „Nauka” 2019, nr 3, s. 147169.

Werner W., Trzoss A., Czy tożsamość kulturowa może być zmierzona? Badania nad mentalnościa z perspektywy Cyfrowej Humanistyki i Obliczeniowych Nauk Społecznych, [w:] Kul'turologì̌nij al'manah: Vipusk 10., Fakul'tet filosofs'koï osvìti ì nauki Kafedra kul'turologiï ta fillosofs'koï antropologiï, Winnica 2018, s. 105-118.

Werner W., Julkowska V., Contemporary Lives of the Past, Poznań 2018.

Wojdon J., Historia w przestrzeni publicznej, Warszawa 2018.

Wysocki A., Stosunek społeczeństwa polskiego do przeszłości a tożsamość narodowa. Analiza badań sondażowych, "Annales Sectio I Philosophy and Sociology" 2018, vol. 43, 1, s. 111-124.

Żuchowicz R., Wielka Lechia. Źródła i przyczyny popularności teorii pseudonaukowej okiem historyka, Warszawa 2018.

Wiktor Werner, Dawid Gralik, Adrian Trzoss

\title{
Media społecznościowe a funkcjonowanie wiedzy historycznej w Polsce. Raport z badań
}

\begin{abstract}
Streszczenie
Artykuł poświęcony jest funkcjonowaniu wiedzy historycznej w Polsce w mediach społecznościowych. Podstawą badania jest badanie ilościowe przeprowadzone drogą internetową w marcu 2019 r. Projekt ankiety, wypełnionej przez 2200 respondentów, został oparty o dotychczasowy dyskurs dotyczący świadomości historycznej. Powołując się na prace Jana Pomorskiego, Barbary Szackiej i Niny Assorodobraj autorzy dokonali zestawienia samooceny wiedzy historycznej użytkowników mediów społecznościowych, ich zainteresowań tematycznych, trendów popularności środków przekazu oraz wpływu mediów epoki przed Web 2.0 (film, telewizja, gry komputerowe). W wyniku przeprowadzonej analizy autorzy stworzyli charakterystykę społecznego zapotrzebowania na narracje historyczne (public history), a także nakreślili obecny stan społecznej roli historii w obszarze, jakim jest rozrywka (cyfrowy homo ludens). Praca ta stanowi element szerszego autorskiego projektu badań nad świadomością historyczną oraz funkcjonowaniu wiedzy historycznej w Polsce z towarzyszącymi mu analizami szczegółowymi zawartymi w innych tekstach.
\end{abstract}

Słowa kluczowe: badania ilościowe, cyfrowy homo ludens, film, gry komputerowe, media społecznościowe, public history, serial, świadomość historyczna, wiedza historyczna 
Wiktor Werner, Dawid Gralik, Adrian Trzoss

\section{Social media and the condition of historical knowledge in Poland. Research report}

\section{Streszczenie}

The article discusses the condition of historical knowledge in Poland in social media. The study is based on a quantitative survey performed online in March 2019. The survey, filled out by 2200 respondents, was designed following the contemporary discourse on historical awareness. Quoting the works of Jan Pomorski, Barbara Szacka, and Nina Assorodobraj, the authors compared self-assessed historical knowledge of social media users with their interests, media popularity trends, and the impact of media of the pre-Web 2.0 era (film, television, computer games). Based on this analysis, the authors created a description of social need for historical narratives (public history), and presented the contemporary condition of the social role of history in entertainment (digital homo ludens). This work is a part of a broader original research project on historical awareness and the condition of historical knowledge in Poland with detailed analyses included in other texts.

Keywords: quantitative study, digital homo ludens, film, computer games, social media, public history, television series, historical awareness, historical knowledge 